\title{
Ellipsis
}

2016

\section{Memorization (for the boy with hibiscus lips)}

\author{
Kayla Fletcher \\ University of New Orleans
}

Follow this and additional works at: https://scholarworks.uno.edu/ellipsis

\section{Recommended Citation}

Fletcher, Kayla (2016) "Memorization (for the boy with hibiscus lips)," Ellipsis: Vol. 43 , Article 8.

DOI: https://doi.org/10.46428/ejail.43.08

Available at: https://scholarworks.uno.edu/ellipsis/vol43/iss1/8

This Poetry is brought to you for free and open access by the Department of English and Foreign Languages at ScholarWorks@UNO. It has been accepted for inclusion in Ellipsis by an authorized editor of ScholarWorks@UNO.

For more information, please contact scholarworks@uno.edu. 


\title{
Memorization \\ (for the boy with hibiscus lips)
}

\author{
Kayla Fletcher
}

I keep hearing about you and people are telling me how long your hair has gotten, how light your eyes are.

The last time I saw you was over a year ago, but you were a different person then, black as licorice, black as oil, the darkness of your narrow veins showed flower stems in your arms and legs, and now you are only a memory; a golden light soaking into my mind. 